\title{
Effectiveness of abundance and biomass curves in detecting environmental alterations in semi-arid region reservoirs
}

\author{
Carlinda Railly Medeiros ${ }^{1 *}$ (D); Evaldo de Lira Azevêdo ${ }^{2}$; José Etham de Lucena Barbosa ${ }^{3}$ \& Joseline Molozzi ${ }^{3}$ \\ ${ }^{1}$ Universidade Federal do Pará, Programa de Pós-Graduação em Ecologia, Belém, PA, Brasil \\ ${ }^{2}$ Universidade Federal Rural de Pernambuco, Programa de Pós-Graduação em Etnobiologia e Conservação da \\ Natureza, Recife, Brasil \\ ${ }^{3}$ Universidade Estadual da Paraiba, Programa de Pós-Graduação em Ecologia e Conservação, Campina Grande, PB, Brasil \\ *Corresponding author: Carlinda RaillyMedeiros, e-mail: carlindarailly@gmail.com
}

MEDEIROS, C.; AZEVÊDO, E.; BARBOSA, E.; MOLOZZI, J. Effectiveness of abundance and biomass curves in detecting environmental alterations in semi-arid region reservoirs. Biota Neotropica. 18(2): e20170423. http:// dx.doi.org/10.1590/1676-0611-BN-2017-0423

\begin{abstract}
For mitigation of environmental problems generated by bad water resource management, the first step is to develop methods for effective diagnosis. The potential bioindicator, mainly in the benthic community, in the evaluation of water quality is the structure of the community, associated with magnitude of environmental impact. The aim of the present study was to evaluate the effectiveness of abundance biomass curves (ABC) as tools to estimate ecological quality in reservoirs in the Brazilian semi-arid region. Two reservoirs, Epitácio Pessoa and Argemiro de Figueiredo were selected. These reservoirs are located in the watershed of the Paraíba River, in Northeast Brazil. Sampling was done at 40 sites in the littoral region of each reservoir, during the periods of higher and lower water volume in the reservoirs. $\mathrm{ABC}$ for semi-arid region reservoirs showed disparate results for biological and environmental indicators, because they had a better relationship with momentary variables (physical and chemical parameters). This may be related to the high occurrence of exotic species, principally Corbicula largillierti, which has a high biomass, in association with a severe drought period. $\mathrm{ABC}$ must thus be used with parsimony and combined with other indicators, for an accurate and coherent characterization.
\end{abstract}

Keywords: Benthic Macroinvertebrates, Environmental Impact, Biomonitoring, Exotic Species.

\section{Eficácia das curvas de abundância e biomassa na detecção de alterações ambientais em reservatórios do semiárido}

\begin{abstract}
Resumo: Para mitigação de problemas ambientais gerados pela má gestão de recursos hídricos, o primeiro passo é o desenvolvimento metodologias de diagnósticos eficientes. O potencial bioindicador, principalmente da comunidade bentônica, na avaliação da qualidade da água deve-se aos aspectos estruturais dessa comunidade, associado com a magnitude de impactos ambientais. O objetivo do presente estudo foi avaliar a eficiência das curvas de biomassa e abundância (ABC) como ferramentas para estimar a qualidade ecológica em reservatórios na região do semi-árido brasileiro. Dois reservatórios, Epitácio Pessoa e Argemiro de Figueiredo foram selecionados. Estes reservatórios estão localizados na bacia do rio Paraíba, no nordeste do Brasil. As coletas foram realizadas em 40 locais na região litorânea de cada reservatório, durante os períodos de maior e menor volume de hídrico. As curvas $\mathrm{ABC}$, quando plotadas em reservatórios do semiárido, apresentaram resultados diferentes aos indicadores biológicos e ambientais, tendo uma relação melhor com as variáveis momentâneas (parâmetros físicos e químicos). Isso pode estar relacionado à alta ocorrência de espécies exóticas, principalmente Corbicula largillierti, o que reflete uma elevada biomassa, combinada com um período severo de seca. O método ABC devem ser utilizadas com parcimônia e associada a outros indicadores, para uma caraterização coerente e precisa.
\end{abstract}

Palavras-chave: Macroinvertebrados bentônicos, Impacto ambiental, Biomonitoramento, Espécies exóticas.

\section{Introduction}

Reservoirs are used for various purposes, such as electrical power generation, irrigation, navigation, leisure, and water supply (Tundisi et al. 2008). The various uses of these ecosystems can end up negatively affecting water quality of aquatic systems (Thorne \& Williams 1997, Bednarek 2001, Abellán et al. 2006). Ecological quality depends on the functional characteristics of an ecosystem, such as the physical and chemical quality of the water, morphometry quality, and functional and structural features of the biological communities (Molozzi et al. 2013). 
Aquatic ecosystems in semi-arid regions have particularities related to low rainfall levels, rain irregularity and high rates of evaporation (Barbosa et al. 2012). In this case, barring rivers and other environmental features of semi-arid regions, such as high salt concentrations, long periods of water retention (about 3 to 5 years) and habitat homogenization, cause biological integrity loss and trophic imbalance and thus alterations in the structure and composition of biological communities (Rocha et al. 2012).

For mitigation of environmental problems generated by inadequate water resource management, the first step is to develop methods for effective diagnosis (Buss 2003). Although water physical and chemical parameters are good estimators of the pollution level of aquatic ecosystems, they overlook the biological communities (Thompson et al. 2008, Camargo et al. 2011). This results in a momentary assessment, which is insufficient to diagnose the ecological quality of aquatic ecosystems (Baptista 2008, Molozzi et al. 2012).

Ecological quality evaluation of aquatic ecosystems has incorporated benthic macroinvertebrates as a biological tool to measure stress factors in continental water ecosystems (Statzner \& Bêche 2010, Pope et al. 2013). Benthic macroinvertebrates exhibit biological traits that reflect ecological integrity in aquatic ecosystems, considering the effects of pollutants over a period of time and including all the dimensions of the ecosystem (Otermin et al. 2002, Sharma \& Rawat 2009). The abundance and biomass of the benthic community are considered important biological attributes for the evaluation of ecological quality. Preserved freshwater ecosystems usually show a lower biomass in the benthic macroinvertebrates community, and an abundance equally distributed, due to low concentrations of dissolved nutrients, and consequently, lower productivity compared to impacted ecosystems (Ahrens \& Peter 1991, Jørgensen et al. 1992, Takahashi et al. 2008, Molozzi et al. 2013).

The use of abundance biomass curves (ABC) as tools for biomonitoring was proposed by Warwick (1986), through the comparison of the curves. This method was first used for the marine macrobenthic community, founded on the evolutionary strategy theories " $\mathrm{k}$ " and " $\mathrm{r}$ ", comparing dominance curves in terms of abundance and biomass (Clarke \& Warwick 2001), according to the perspective that the distribution of the numerical abundance of organisms and total biomass do not show the same pattern in ecosystems subject to different levels of pollution (Marques et al. 2009). The theory founded on the evolutionary strategies " $k$ " and " $r$ " suggests that in environments under stable conditions, with less disturbance, it is expected that the biomass curve rises above the abundance curve, classifying the environment as non-polluted. In such scenario, the community is likely dominated by " $\mathrm{k}$ " strategist species with one or two species at high biomass levels, but showing low abundance of species (Yemane et al. 2005). These species are characterized as having slow growth, late maturation, and large body size, and being rarely dominant in terms of abundance, although they are dominant in terms of biomass (Yemane et al. 2005). On the other hand, curves can also tend to overlap, identifying a moderately disturbed environment, when the community shows "k" species being replaced by " $r$ " species, which show fast growth and are dominant in terms of biomass and number (Yemane et al. 2005, Puente \& Diaz 2008, Carvalho et al. 2013). When the abundance curve rises above the biomass curve, the environment is classified as severely polluted, because the community is theoretically dominated by " $\mathrm{r}$ " species, with smaller body size, but with high numerical abundance (Carvalho et al. 2013).

In evaluating the ecological quality of aquatic ecosystems, several aspects must be incorporated for a comparative and complementary classification (Molozzi et al. 2013). The aim of this study was to evaluate the effectiveness of biomass abundance curves (ABC) as tools to estimate ecological quality in reservoirs in the Brazilian semi-arid region. The study comparing $\mathrm{ABC}$ with other ecological and environmental indicators is important to evaluate the concordance of such curves with the description of ecological conditions in semi-arid region reservoirs.

\section{Material and Methods}

Two reservoirs, Epitácio Pessoa and Argemiro de Figueiredo were selected. These reservoirs are located in the watershed of the Paraíba River, in Northeast Brazil (Figure 1). Minimum air temperature is in July and

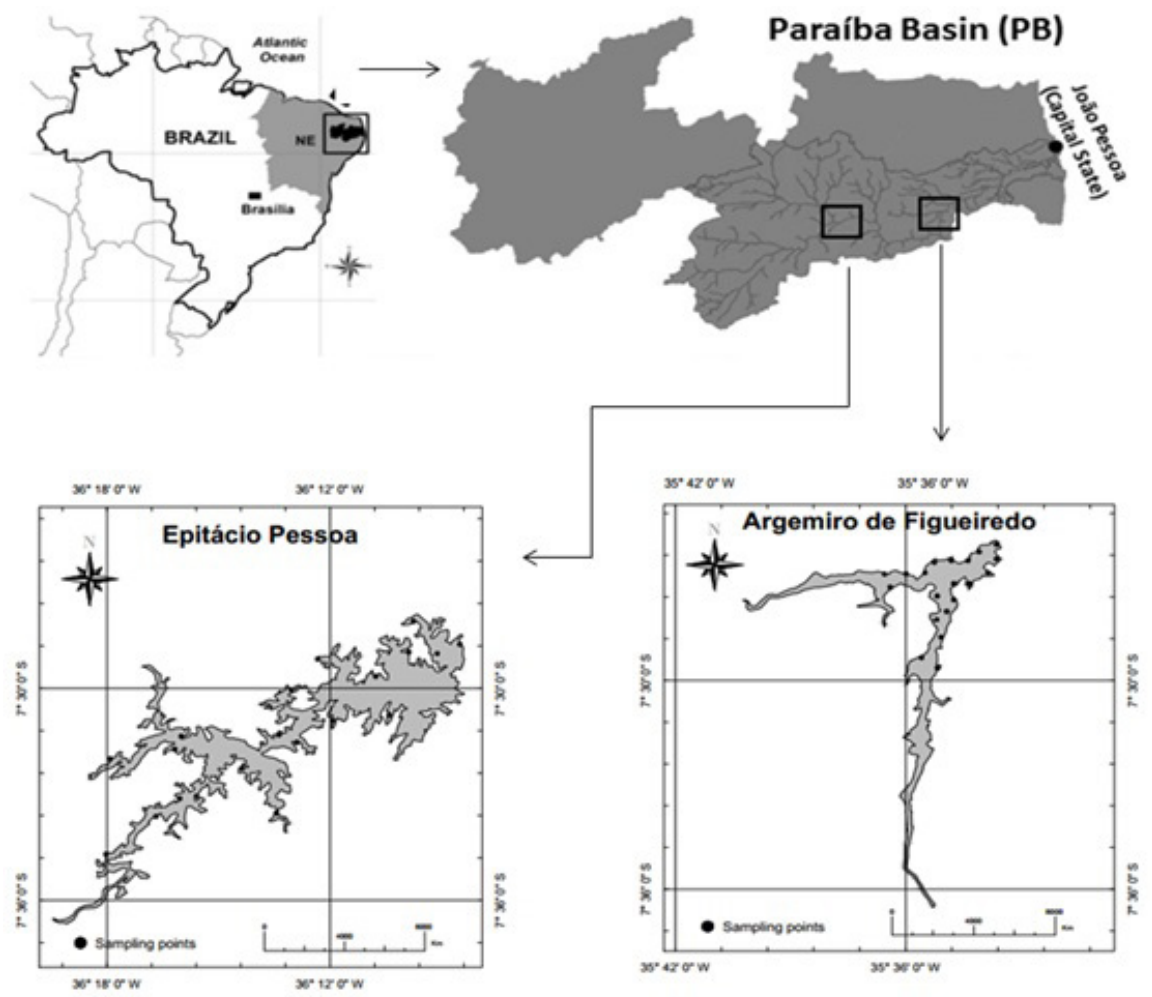

Figure 1. Geographical location of Epitácio Pessoa and Argemiro de Figueiredo reservoirs in the watershed of the Paraíba River, in Brazil. The points in the figure indicate the sampling sites. 
August $\left(18-22^{\circ} \mathrm{C}\right)$, and maximum in November and December $\left(28-31^{\circ} \mathrm{C}\right)$. The climate of the region is BSh semi-arid hot (Köppen-Geiger 1936), with average rainfall of $400 \mathrm{~mm} /$ year (AESA 2013). The watershed of the Paraiba River is the second largest in Paraiba State. It is composed of the sub-watershed of the Taperoá River and regions of the upper, middle and lower course of the Paraiba River. It includes a $20.072 \mathrm{~km}^{2}$ area, with maximum capacity of $1.078 .104 .307 \mathrm{~km}^{3}$ of accumulated water and about 1.828.178 inhabitants in its coverage area (AESA 2013).

The Epitácio Pessoa Reservoir (7²7.5'3”S; 35³5'52.6”W) was constructed in 1956, and is located in the division between the upper and middle course of the Paraiba River with drainage basin of 26.784 ha, accumulation capacity of 418 million $\mathrm{m}^{3}$ and hydraulic retention time of 3 to 5 years. Argemiro de Figueiredo Reservoir (7'29'20'S; $36^{\circ} 17^{\prime} 3$ ' W) was constructed in 2001, located in the middle and lower course of the Paraiba River, with drainage basin of 2.300 ha, accumulation capacity of 253 million $\mathrm{m}^{3}$ and hydraulic retention time of 3 to 5 years. The main use of the reservoirs is for water supply, but they are also used for other activities such as fishing, leisure, regional tourism and irrigation.

In each reservoir, sampling was conducted at twenty sites in the littoral region in periods of higher and lower water volume, representing variations in the benthic macroinvertebrates community between seasonal periods. The higher water volume in the reservoirs was observed in December (2011), when we recorded in the Epitácio Pessoa Reservoir $373.957 .565 \mathrm{~m}^{3}$ of water $(90.8 \%$ of its maximum capacity), and in the Argemiro de Figueiredo Reservoir $206.397 .908 \mathrm{~m}^{3}$ of water $(81.6 \%$ of its maximum capacity). Meanwhile, in July (2012), we recorded the lower volume in the reservoirs, i.e., $308.826 .158 \mathrm{~m}^{3}$ for Epitácio Pessoa (75\% of maximum) and $143.367 .467 \mathrm{~m}^{3}$ for Argemiro de Figueiredo (56.7\% of maximum) (AESA 2014).

The macroinvertebrates were sampled using a Van Veen dredge $\left(500 \mathrm{~cm}^{2}\right.$ area). The sediment samples were fixed in situ in $4 \%$ formaldehyde. In the laboratory, the samples were washed with overlapping sieves $(1.00-0.50 \mathrm{~mm})$, preserved in alcohol $(70 \%)$ and identified to the family level (Mugnai et al. 2010), except for the family Chironomidae, in which identification was to the genus level (Trivinho-Strixino 2011).

After taxonomic identification, the organisms were dried in an oven at $60^{\circ} \mathrm{C}$ for 72 hours and weighed (accuracy of $10^{-5} \mathrm{mg}$ ) for biomass determination. The individuals of the phylum Mollusca were burned in a muffle furnace at $450^{\circ} \mathrm{C}$ for 4 hours to estimate the ash free dry weight (Azevêdo et al. 2015).

In each sampling period and at each sampling site, physical and chemical variables were measured in situ using a multiparameter probe (Horiba/U-50): dissolved oxygen $(\mathrm{mg} / \mathrm{L})$, electrical conductivity $(\mathrm{mS} / \mathrm{cm})$, turbidity (NTU) and $\mathrm{pH}$. Water samples were collected in the sub-surface with a Van Dorn type bottle for subsequent analysis of total nitrogen (TN), total phosphorus (TP), nitrite $\left(\mathrm{NO}_{2}^{-}\right)$, nitrate $\left(\mathrm{NO}_{3}^{-}\right)$, ammonium ion $\left(\mathrm{NH}_{3}^{-}\right)$ and reactive soluble phosphate $\left(\mathrm{PO}_{4}^{-}\right)$, in accordance with the "Standard Methods for the Examination of Water and Wastewater" (APHA 2005). The concentration of chlorophyll- $a$ (Chla) was determined according to Lorezen (1967). Transparency was estimated using a Secchi disk, and water column depth was estimated using a portable sonar (Laylin Associates SM5 SM-5).

For the characterization of the physical aspects of the habitat and anthropic disturbance in the reservoirs, ten protocols of physical habitat characterization were applied at each sampling site, totaling 200 protocols applied for each study reservoir according to methods determined by the US Environmental Protection Agency (USEPA 2012). The protocol was applied only in the period of higher water volume in the reservoirs. Observations were taken from three areas: littoral zone $(10 \mathrm{~m}$ wide and $15 \mathrm{~m}$ length), floodplain (15 $\mathrm{m}$ width and variable length), and riparian zone (15 $\mathrm{m}$ width and $15 \mathrm{~m}$ long).
The protocol evaluates physical features of habitats such as the bottom substrate from the littoral zone, presence and types of macrophytes, potential shelters for fish, riparian and flooding zone dossal, and type of ground vegetation, along with the assessment of human influences such as construction, trade, transmission lines or trash, and grain crops. For this study, information was used about human disturbance around the reservoirs, and disturbance metrics were established for the flooding zone (Kaufmann et al. 2014, Azevêdo et al. 2017).

Metrics of anthropic disturbance in the flooding zones were determined according to the methods developed by the Environmental Protection Agency of the USA (USEPA, 2012; Kaufmann et al. 2014).

In this work, the intensity and extension indices of human disturbance were used, considering 12 types of human disturbance activities. Four activities are related to agriculture (grain crop fields, pastures, orchards, grass/parks) and eight activities are related to other types of disturbances (constructions, trade, artificial beaches, docks/boats, walls/dikes, trash, roads, railroads, transmission lines). The disturbance metric was determined as the absence of disturbance corresponding to weight 0 , the disturbance inside of the parcel with weight 1 , and disturbances adjacent to the analyzed parcel with weight 0.5 . The values were then used for final metric calculation. The index of the final metric included values varying from 0 to 1 . Values closest to 0 indicated smaller degrees of disturbance, and values closest to 1 indicated more intense disturbances. The metric values were characterized as follows: from 0 to 0.30 was a smaller disturbance degree, 0.31 to 0.6 was a moderate disturbance degree and 0.61 to 1 was more intense disturbance degree (Kaufmann et al. 2014).

The Shannon-Wiener diversity index (Shannon \& Weaver 1963) and taxonomic richness were used as comparative parameters with $\mathrm{ABC}$ method, to improve explicability of the overlapping of the curves in the periods of higher and lower water volume, and between reservoirs.

The disturbance degree in the reservoirs was estimated using the ABC method proposed by Warwick (1986), based on ABC tendencies. In impacted environments, abundance curve is above biomass curve; in moderately disturbed environments, abundance and biomass curves tend to overlap; and in low level disturbance systems, biomass curve is above abundance curve.

The $\mathrm{W}$ index is the numerical summarization of the $\mathrm{ABC}$, measuring differences in the overlap of the curves, assuming the values: +1 , indicating undisturbed systems; -1 , indicating disturbed systems; and 0 , indicating moderately disturbed systems. The values were generated in combination with the ABC for classification of the reservoirs (Marques et al. 2009).

The index is given by Eq. 1:

$$
\mathrm{W}=\Sigma(\mathrm{Bi}-\mathrm{Ai}) /[50(\mathrm{~S}-1)]
$$

where $B i$ is the biomass of species $i, A i$ the abundance of species $i$ and $S$ the number of species (Warwick \& Clarke, 1994).

Permutational multivariate analysis of variance (PERMANOVA) was used to assess the differences between the environmental parameters biomass and abundance, where $\mathrm{p} \leq 0.05$ was considered statistically significant (Anderson et al. 2008). The factors established were: reservoirs (two levels: Epitácio Pessoa and Argemiro de Figueiredo) and seasonal periods (two levels: higher and lower water volumes). Euclidean distance was used as the dissimilarity measure for environmental parameters. The Bray Curtis similarity matrix was calculated and used to generate a two-dimensional plot using the non-metric multidimensional scaling (NMDS) analysis (Clarke \& Warwick 2001, Clarke \& Gorley 2006). The biological data (species abundance and biomass) were square-root transformed and environmental data $\log _{(x+1)}$ transformed. The software used was PERMANOVA + for PRIMER, 2006 (Systat Software, Cranes Software International Ltd. 2008). 
The influence of exotic species on taxonomic richness and Shannon-Wiener diversity was assessed using simple regression (Spearman rank correlation), with the aim of better understanding the pattern of the curves due to the high abundance of exotic species observed. Statistic 7.0 software was used to determine correlations.

\section{Results}

The waters in the Argemiro de Figueiredo Reservoir was slightly more alkaline in the two seasonal periods when compared to the waters of the Epitácio Pessoa Reservoir (Table 1). Epitácio Pessoa showed higher concentrations of total phosphorus $\left(1043 \mu \mathrm{gL}^{-1}\right)$ in the period of higher water volume and of organic nitrogen $\left(53.42 \mu \mathrm{gL}^{-1}\right)$ in the period of lower water volume (Table 1). The physical and chemical variables were significantly different between Argemiro de Figueiredo and Epitácio Pessoa (PERMANOVA: Pseudo- $\left.\mathrm{F}_{1.79}=52.481 ; \mathrm{p}=0.001\right)$ and between the periods of higher and lower water volume (PERMANOVA: Pseudo- $F_{1.79}=47.601 ; \mathrm{p}=0.001$ ).

The metrics established from the protocol of physical habitat characterization, related to human disturbance, showed that Argemiro de Figueiredo included $60 \%$ of the sites classified as having good environmental quality, with metrics varying from 0 to 0.30 (Figure 2). In $30 \%$ of sampling sites, the disturbance metrics varied from 0.31 to 0.6 , demonstrating moderate disturbance levels and $10 \%$ with metrics from 0.61 to 0.80 , classified as impacted (Figure 2). The more elevated disturbance metrics were related to construction, trash presence and pasture. For Epitácio Pessoa, 30\% of the sites had metrics of anthropic disturbance of 0 to 0.30 , classifying them as having good environmental quality, $60 \%$ of the metrics varied from 0.31 to 0.60 , classifying those sites as moderately disturbed, and $10 \%$ varied from 0.61 to 0.90 classifying those sites as impacted (Figure 2). The sites with the most elevated metrics were associated with pastures, transmission lines, construction, trade, and trash, which reflects use and occupation around the reservoir.

At Argemiro de Figueiredo reservoir there was overlap in the $\mathrm{ABC}$ during the lower (Figure 3A) and higher water volume (Figure 3B) classifying it as moderately disturbed. This result was supported by the $\mathrm{W}$ index during the lower (Figure $3 \mathrm{~A}$ ) and higher (Figure 3B) water volume $(\mathrm{W}=0.009$ and 0.024 , respectively), classifying also the reservoir as moderately perturbed for both periods. In Epitácio Pessoa, the biomass curve was above of the abundance curve during the lower water volume (Figure 4A). In the period of higher water volume, the $\mathrm{ABC}$ classified the reservoir as moderately disturbed through the overlapping of the ABC (Figure 4B). The W index classified the Epitácio Pessoa reservoir as moderately disturbed in the period of lower water volume $(\mathrm{W}=0.207)$ and also in the period of higher water volume $(\mathrm{W}=0.046)$.

The macroinvertebrates community were represented by 17.573 individuals distributed in 14 taxa (3 Mollusca, 2 Annelida, 6 Diptera, 2 Odonata and 1 Crustacea) (Table 2). Argemiro de Figueiredo was more representative in terms of abundance (14.536 individuals) compared to Epitácio Pessoa (3.037 individuals) (Figure 5A). In terms of the biomass of organisms, Argemiro de Figueiredo showed $112.6 \mathrm{mg} / \mathrm{m}^{2}$ and Epitácio Pessoa $49.67 \mathrm{mg} / \mathrm{m}^{2}$ (Table 2; Figure 5B).

In the period of lower water volume, Argemiro Figueiredo had high abundance of the exotic species Melanoides tuberculatus (MÜLLER, 1774) (96\%), followed by Goeldichironomus $(0.56 \%)$ and Oligochaeta $(0.31 \%)$ (Figure $6 \mathrm{~A})$. In terms of biomass, the most common benthic macroinvertebrates were $M$. tuberculatus (93\%), Planorbidae (4\%) and Oligochaeta $(1.9 \%)$ (Figure $6 \mathrm{C}$ ). In the period of higher water volume in Argemiro de Figueiredo, M. tuberculatus represented the community with proportions of $98 \%$ of total abundance, followed by Hirudinea $(0.9 \%)$ and Fissimentum ( $0.6 \%$ ) (Figure 6A). The biomass of the benthic macrofauna was represented by larger proportions of M. tuberculatus $(90 \%)$, followed by Parachironomus (4\%) and Fissimentum (1\%) (Figure 6C).

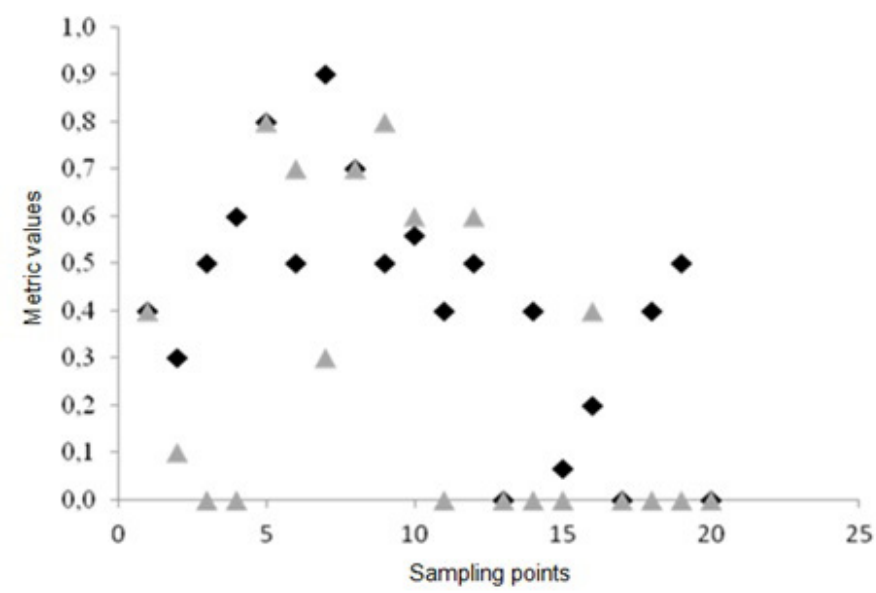

Figure 2. Dispersion of the metrics - characterization protocol of physical habitat for inundation zone in the Argemiro de Figueiredo and Epitácio Pessoa reservoirs. The gray symbols represent the Argemiro de Figueiredo reservoir and black symbols represents the Epitácio Pessoa reservoir.

Table 1. Mean and standard deviation of the physical and chemical variables in the Argemiro de Figueiredo and Epitácio Pessoa reservoirs, between periods of lower and higher water volume, sampled in the years 2011/2012. The $\left(^{*}\right)$ indicates the variables that show differences between the reservoirs.

\begin{tabular}{|c|c|c|c|c|}
\hline \multirow{2}{*}{$\begin{array}{c}\text { Reservoir } \\
\text { Estation }\end{array}$} & \multicolumn{2}{|c|}{ Argemiro de Figueiredo } & \multicolumn{2}{|c|}{ Epitácio Pessoa } \\
\hline & Lower volume & Higher volume & Lower volume & Higher volume \\
\hline Water temperature $\left({ }^{\circ} \mathrm{C}\right)$ & $28.84 \pm 0.86$ & $29.07 \pm 0.61$ & $26.52 \pm 0.80$ & $28.09 \pm 2.55$ \\
\hline $\mathrm{pH}$ & $9.31 \pm 0.25$ & $7.97 \pm 0.26$ & $9.21 \pm 0.66$ & $7.98 \pm 0.57$ \\
\hline Orthophosphate (mV) & $127.15 \pm 8.84$ & $202.55 \pm 12.68$ & $108.25 \pm 23.74$ & $199.90 \pm 23.15$ \\
\hline Electrical Conductivity $\left(\mu \mathrm{S} / \mathrm{cm}^{-1}\right)$ & $1.23 \pm 0.00$ & $1.11 \pm 0.00$ & $0.86 \pm 0.02$ & $0.76 \pm 0.04$ \\
\hline Turbidity (NTU) & $60.86 \pm 26.87$ & $96.17 \pm 84.23$ & $40.49 \pm 74.83$ & $123.19 \pm 181.48$ \\
\hline Dissolved Oxygen $\left(\mathrm{mg} / \mathrm{L}^{-1}\right)$ & $8.68 \pm 1.35$ & $9.83 \pm 0.68$ & $8.41 \pm 1.29$ & $7.94 \pm 1.84$ \\
\hline Total Dissolved Solids $\left(\mathrm{mg} / \mathrm{L}^{-1}\right)$ & $0.79 \pm 0.00$ & $0.71 \pm 0.00$ & $0.55 \pm 0.01$ & $0.49 \pm 0.02$ \\
\hline Salinity (\%) & $0.06 \pm 0.00$ & $0.05 \pm 0.00$ & $0.04 \pm 0.00$ & $0.04 \pm 0.00$ \\
\hline "Alkalinity (mg) & $23.50 \pm 2.41$ & $22.25 \pm 1.33$ & $16.35 \pm 1.92$ & $15.35 \pm 4.94$ \\
\hline${ }^{*}$ Total Phosphorus $\left(\mu \mathrm{g} / \mathrm{L}^{-1}\right)$ & $543.70 \pm 105.70$ & $366 \pm 62.39$ & $448.52 \pm 89.73$ & $1043 \pm 187$ \\
\hline Phosphates $\left(\mu \mathrm{g} / \mathrm{L}^{-1}\right)$ & $184.62 \pm 8.14$ & $38.50 \pm 19.92$ & $196.24 \pm 241.95$ & $53.75 \pm 79.81$ \\
\hline${ }^{*}$ Organic Nitrogen $\left(\mu \mathrm{g} / \mathrm{L}^{-1}\right)$ & $43.31 \pm 342.43$ & $30.97 \pm 467.23$ & $66.73 \pm 267.41$ & $53.42 \pm 161.69$ \\
\hline
\end{tabular}


A)

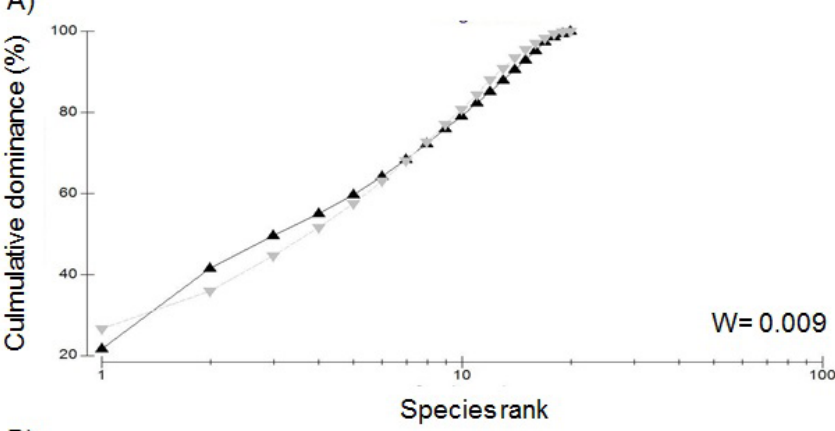

B)

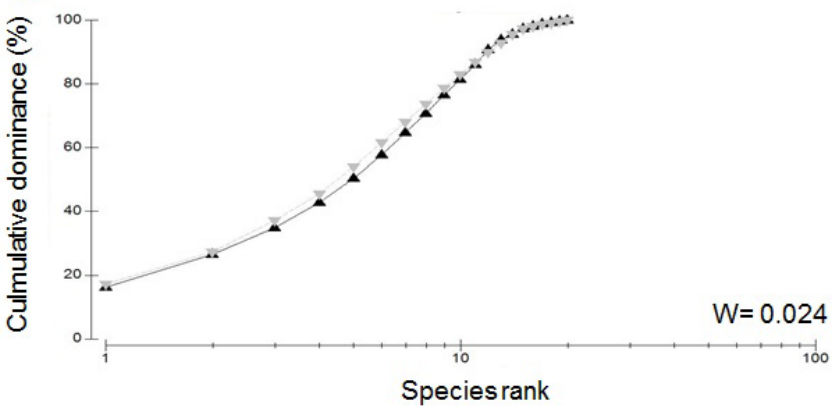

Figure 3. Trends in abundance (black symbols) and biomass (gray symbols) curves in the Argemiro de Figueiredo Reservoir in the periods of lower (A) and higher water volume (B).
A)

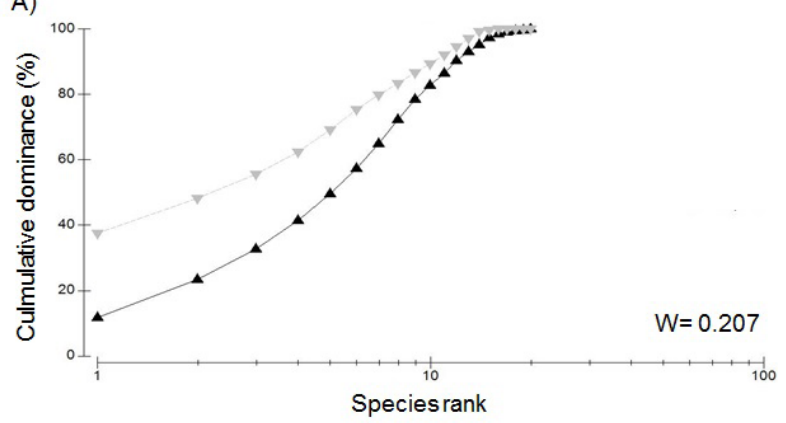

B)

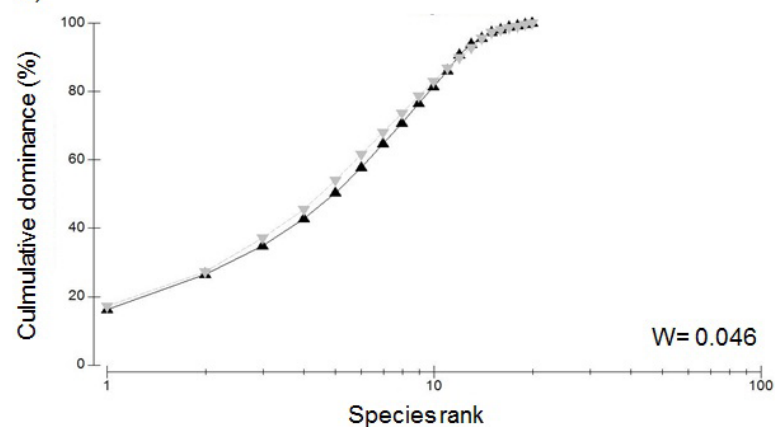

Figure 4. Trends in abundance (black symbols) and biomass (gray symbols) curves in the Epitácio Pessoa Reservoir in the periods of lower (A) and higher water volume (B).

Table 2. Mean and standard deviation for the abundance (total number of individuals), biomass (mg-2), richness (number of species) and Shannon-Winner diversity of benthic community of the Argemiro de Figueiredo and Epitácio Pessoa reservoirs during periods of lower and higher water volume. The (*) indicates no occurrence.

\begin{tabular}{|c|c|c|c|c|c|c|c|c|}
\hline & \multicolumn{4}{|c|}{ Argemiro de Figueiredo } & \multicolumn{4}{|c|}{ Epitácio Pessoa } \\
\hline & \multicolumn{2}{|c|}{ Lower volume } & \multicolumn{2}{|c|}{ Higher volume } & \multicolumn{2}{|c|}{ Lower volume } & \multicolumn{2}{|c|}{ Higher volume } \\
\hline & Abundance & Biomass & Abundance & Biomass & Abundance & Biomass & Abundance & Biomass \\
\hline \multicolumn{9}{|l|}{ MOLLUSCA } \\
\hline Melanoide tuberculatus, Müller, 1774 & $506 \pm 604.03$ & $1.11 \pm 60.53$ & $195 \pm 160.99$ & $4.52 \pm 3.96$ & $35 \pm 31.45$ & $8.62 \pm 994.57$ & $107 \pm 105.10$ & $4.90 \pm 2.29$ \\
\hline Corbicula largilierti, Philippi, 1844 & $*$ & $*$ & $*$ & $*$ & $1 \pm 0.99$ & $481,55 \pm 491.46$ & $*$ & $*$ \\
\hline Planorbidae & $2 \pm 4.12$ & $708.60 \pm 99.70$ & * & $*$ & $*$ & $*$ & $1 \pm 0.78$ & * \\
\hline \multicolumn{9}{|l|}{ ANÉLIDA } \\
\hline Oligochaeta & $16 \pm 50.69$ & $0.18 \pm 0.01$ & $1 \pm 0.22$ & * & $4 \pm 8.82$ & $0.01 \pm 0.04$ & $4 \pm 15.60$ & $0.01 \pm 0.06$ \\
\hline Hirudínea & $*$ & $*$ & $2 \pm 7.13$ & * & $*$ & $*$ & $1 \pm 0.22$ & $2.07 \pm 2.23$ \\
\hline DIPTERA & & & & & ‘ & & & \\
\hline Ceratopogonidae & * & * & $1 \pm 1.43$ & $0.09 \pm 0.02$ & $1 \pm 0.67$ & $3.30 \pm 0.22$ & * & * \\
\hline Goeldichironomus, Fittkau, 1965 & $3 \pm 11.85$ & $0.10 \pm 0.45$ & * & * & * & * & $1 \pm 0.30$ & $0.08 \pm 0.26$ \\
\hline Fissimentum, Cranston; Nolte, 1996 & * & * & $1 \pm 2.03$ & $0.32 \pm 0.06$ & $1 \pm 0.22$ & $4.10 \pm 0.07$ & $1 \pm 1.34$ & $3.53 \pm 1.11$ \\
\hline Parachironomus, Lenz, 1921 & * & * & $1 \pm 0.22$ & $1.90 \pm 0.09$ & $*$ & $*$ & $1 \pm 0.30$ & $1.5 \pm 6.70$ \\
\hline Aedokritus, Roback, 1958 & * & * & $*$ & $*$ & $1 \pm 0.31$ & $1.40 \pm 0.12$ & $*$ & $*$ \\
\hline Coelotanypus, Kieffer, 1913 & * & * & * & * & $1 \pm 0.22$ & $8.90 \pm 0.10$ & * & * \\
\hline \multicolumn{9}{|l|}{ ODONATA } \\
\hline Libellulidae & * & * & ${ }^{*}$ & * & $1 \pm 0.22$ & $0.20 \pm 0.09$ & $1 \pm 0.22$ & $0.19 \pm 0.02$ \\
\hline Corixidae & * & * & $1 \pm 0.67$ & $0.10 \pm 0.03$ & $*$ & $*$ & $*$ & * \\
\hline \multicolumn{9}{|l|}{ CRUSTACEA } \\
\hline Decápode & * & * & $*$ & $*$ & $2 \pm 5.23$ & $0.19 \pm 0.63$ & $*$ & $*$ \\
\hline Abundance (number of individuals) & 10541 & * & 3995 & * & 814 & * & 2223 & * \\
\hline Richness (number of species) & 4 & * & 8 & * & 9 & * & 8 & * \\
\hline Diversity of Shannon & 0.09 & $*$ & 0.11 & $*$ & 0.31 & $*$ & 0.11 & $*$ \\
\hline
\end{tabular}

Abundance in Epitácio Pessoa in the period of lower water volume was represented by the exotic gastropod M. tuberculatus with proportions of $84 \%$ for the benthic community, followed by Oligochaeta $(9.1 \%)$ and Decapoda (4.67\%) (Figure 6B). The biomass of the benthic macrofauna was represented in larger proportions by the two exotic species Corbicula largillierti (Philippi, 1844) (67\%) and M. tuberculatus (35\%), followed by Coelotanypus (Diptera) (1.5\%) (Figure 6D). In the higher water volume period of Epitácio Pessoa, the abundance and biomass of the community 
A)

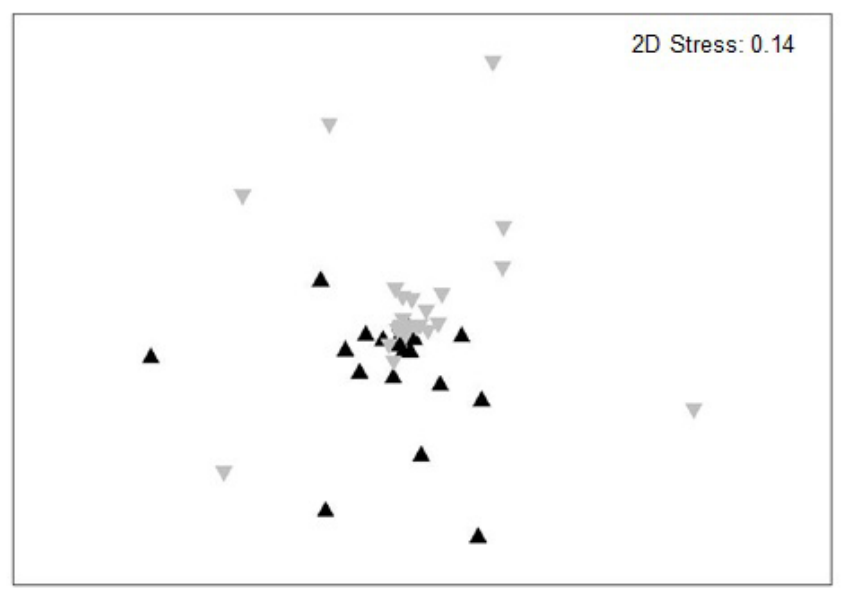

B)

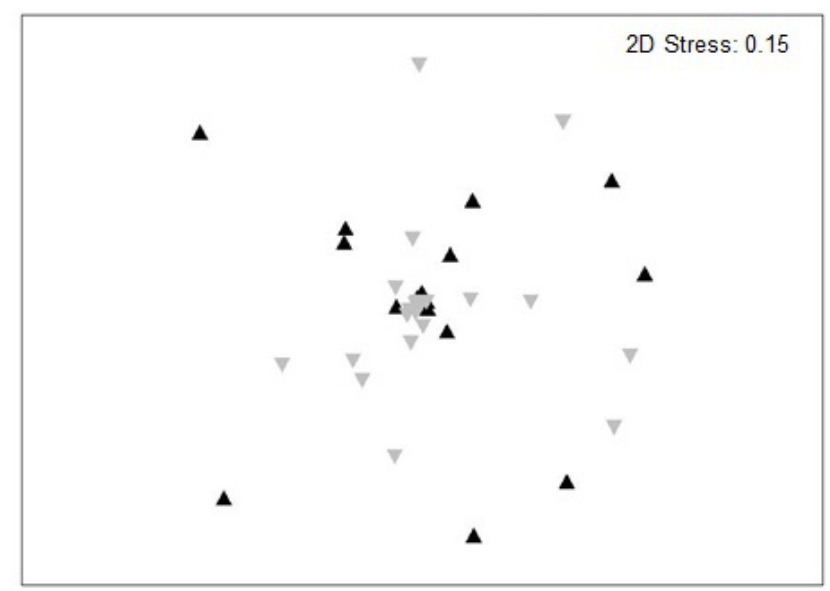

Figure 5. Non-metric multidimensional scaling (NMDS) analysis showing the spatial distribution of abundance (A) and biomass (B) of the benthic macroinvertebrates community. The gray symbols represent the Argemiro de Figueiredo reservoir and black symbols represents the Epitácio Pessoa reservoir.

A)

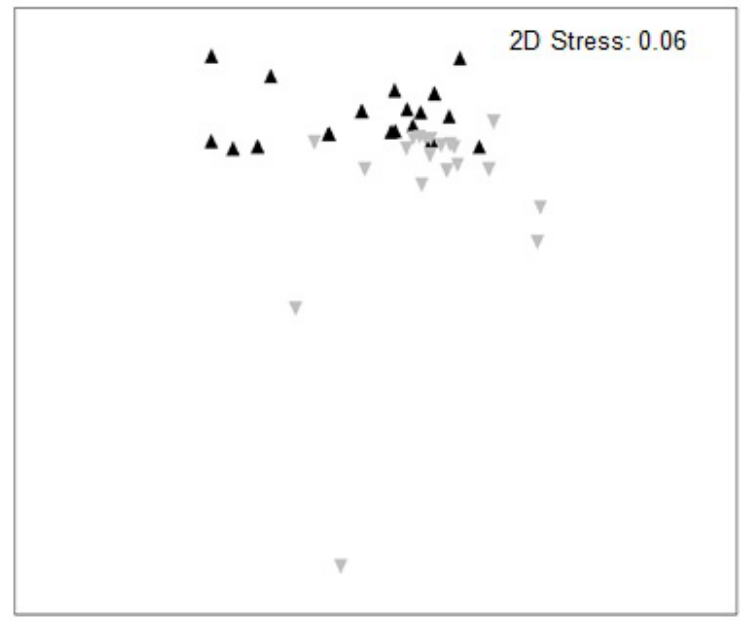

C)

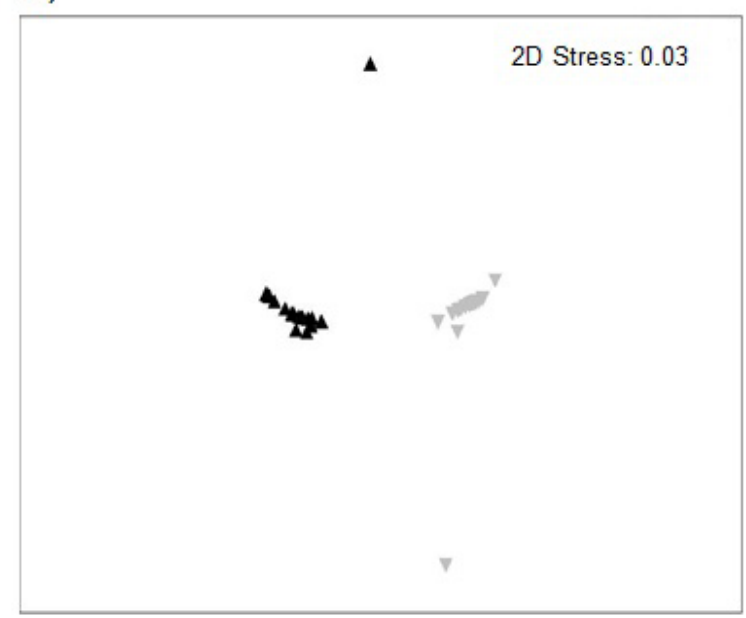

B)

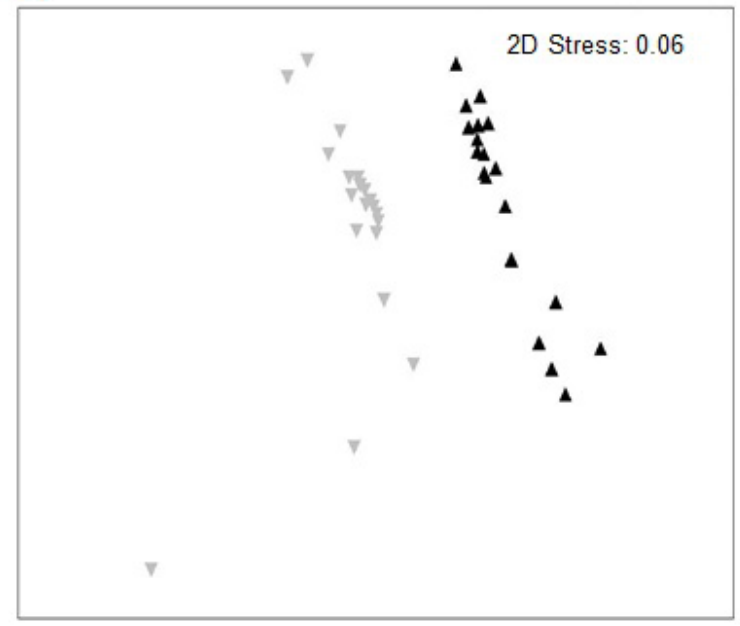

D)

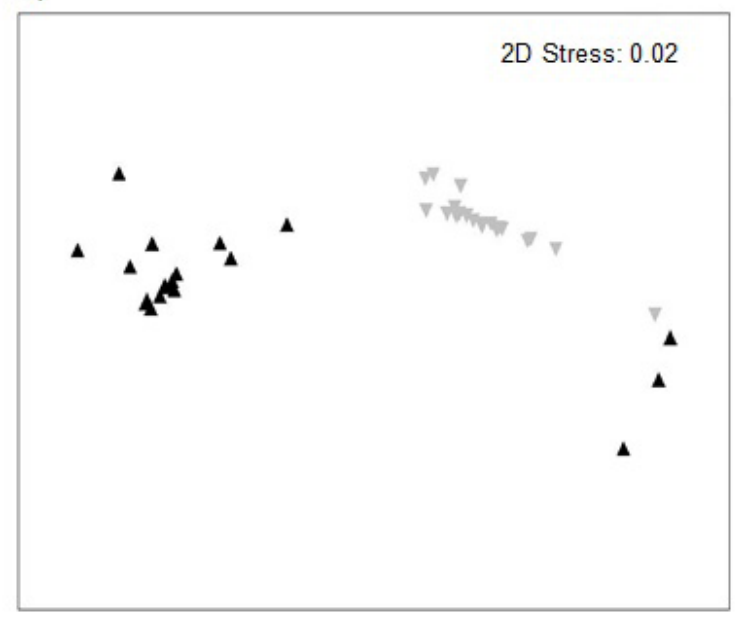

Figure 6. Non-metric multidimensional scaling (NMDS) analysis showing the spatial distribution in the periods at lower (black symbols) and higher water volume (gray symbols), for abundance (A and B) and biomass (C and D) of the benthic macroinvertebrates community of the Argemiro de Figueiredo (A and C) and Epitácio Pessoa (B and D) reservoirs, in the Paraíba River, Paraíba, Brazil. 

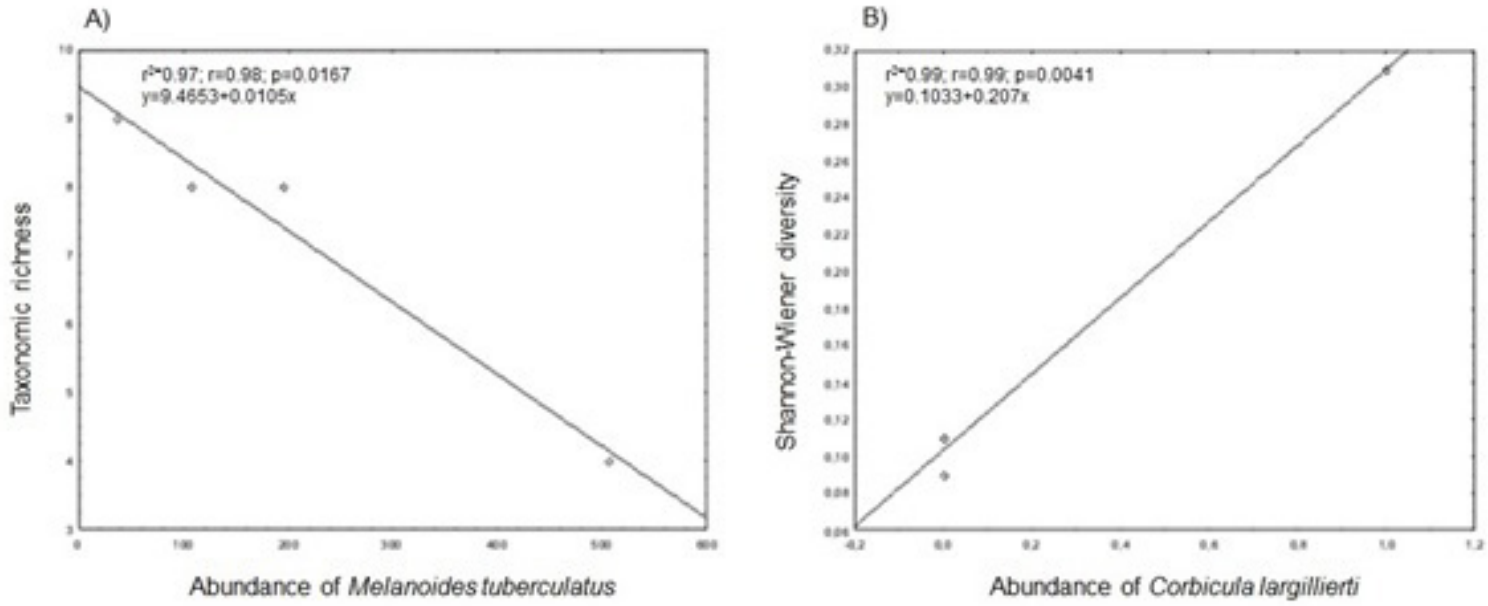

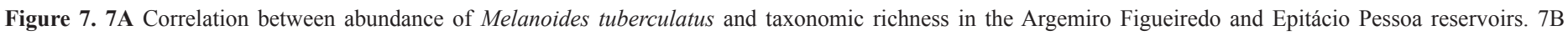

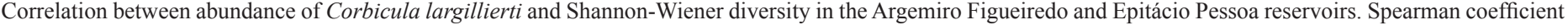
is shown in each graph.

were represented in equal proportions by $M$. tuberculatus, ( $95 \%$ ), followed by Oligochaeta (3\%), and Planorbidae mollusks $(0.27 \%)$ for abundance (Figure $6 \mathrm{~B})$, and in terms of biomass, Hirudinea (2\%) and Fissimentum (1\%) (Figure 6D).

The taxonomic richness of the macroinvertebrates in the Epitácio Pessoa reservoir was more representative in the period of lower volume in the reservoir ( 9 taxa), followed by the period of higher hydric volume ( 8 taxa). The opposite occurred in the Argemiro de Figueiredo reservoir, where richness was more elevated in the period of higher water volume in the reservoir ( 8 taxa) when compared to the period of lower water volume (4 taxa) (Table 2). The correlation suggests that as M. tuberculatus abundance increases, taxonomic richness decreases $\left(\mathrm{r}^{2}=0.97 ; \mathrm{p}=0.016\right)$ (Figure 7A); however, a significant correlation with $C$. largillierti $\left(\mathrm{r}^{2}=0.99 ; \mathrm{p}=0.0041\right)$ was observed.

The Shannon-Wiener diversity was greater in Epitácio Pessoa, with values of 0.31 at lower water volume and 0.11 bits at higher water volume (Table 2). The index represented the diversity in Argemiro de Figueiredo, with values of 0.11 at higher water volume and 0.09 at lower water volume (Table 2). Significant differences occurred between the reservoirs in diversity (PERMANOVA: Pseudo- $\mathrm{F}_{3.1}=1.2777 ; \mathrm{p}=0.654$ ) and richness (PERMANOVA: Pseudo- $F_{3.1}=1.2912 ;=0.659$ ). Linear regression did not show a significant correlation between Shannon-Wiener diversity and abundance of $M$. tuberculatus $\left(\mathrm{r}^{2}=0.40 ; \mathrm{p}>0.05\right)$, but rather a correlation between Shannon-Wiener diversity and C. largillierti $\left(\mathrm{r}^{2}=0.99 ; \mathrm{p}<0.004\right)$ (Figure 7B).

\section{Discussion}

Our results suggest that the $\mathrm{ABC}$ method shows variation opposite to the theory proposed by Warwick (1986) for semi-arid reservoirs. According to the theory, impacted environments there are species with high numbers of individuals and with small body size, which results in the positioning of the abundance curve above the biomass curve. Our results showed the opposite. In this study, the biomass curve over the abundance curve classified the Epitácio Pessoa Reservoir in the lower water volume period of the reservoir as being impacted. The inverse ABC classification was associated with the presence of the exotic species $C$. largillerti, abundant in terms of biomass. This classification was confirmed by the $\mathrm{W}$ index, which was also high when compared to the index values that classified the Argemiro de Figueiredo Reservoir as moderately disturbed. The increase in $\mathrm{W}$ index when impact levels increase was also identified by Reizopoulou et al. (1996).

Environments with greater organic enrichment provide a larger biomass of exotic species, as observed by other authors (Callisto et al. 2005, Velho et al. 2005, Elkarmi \& Ismail 2007, Peso et al. 2011, Molozzi et al. 2013), which is often determined by anthropic actions (Borja et al. 2009, Tafangenyasha \& Dube 2008). This is associated with an increase in productivity in those ecosystems, which makes the rise in metabolic rates and lifespan possible, allowing the dominance of some opportunist species.

Both reservoirs harbored the exotic species M. tuberculatus, which might have influenced the proximity between abundance and biomass curves, in both seasonal periods for the Argemiro de Figueiredo Reservoir, and in the higher water volume period for the Epitácio Pessoa Reservoir. M. tuberculatus is an exotic species that, in a disturbed environment, shows a larger size in relation to other species of the benthic community (Molozzi et al. 2013). The proximity between the curves is explained by other authors as the elimination of specialist species, allowing the existence of " $r$ " strategist species, abundant in terms of number of individuals, increasing the tendency of the abundance curve, and consequently, causing the curves to be closer (Clarke 1990, Carvalho et al. 2013, Magurran 2013).

The ecological indicators, based on the richness and diversity of the community of benthic macroinvertebrates in the reservoirs studied displayed a response at odds with the ABC. Opportunist and exotic species cause changes in the structure of macrobenthic communities because of their high capacity for invasion and competition (Harkantra \& Rodrigues 2014). We believe that in cases where the two exotic species $M$. tuberculatus and C. largilliert both occurred, there was competition between them, which caused a decrease in the occurrence of $M$. tuberculatus and increase in the diversity of the benthic community.

Santos and Eskinazi-Sant'Anna (2010) investigated the introduction of M. tuberculatus in reservoirs in the semi-arid region and found that exotic species caused a decline in native species, decreasing their abundance, whereas opportunist species benefited and often became dominant in terms of biomass, leading to alterations in biological communities, which, in general, put the biodiversity and ecological balance of water ecosystems at risk. This could be seen in the reservoirs studied, where the exotic gastropod M. tuberculatus, considered an exotic " $r$ " species, with high ecological and tolerant plasticity to different pollution gradients (Abílio et al. 
2007, Molozzi et al. 2012, Azevêdo et al. 2014), negatively affected the abundance, richness, and diversity of native species, as indicated by the low representativeness of those species in the study.

When the environmental indicators for Argemiro de Figueiredo were analyzed, the metrics of physical habitat characterization were discordant in most periods, classifying the reservoir as having good environmental quality. This discordance in classification is due to the morphological characteristics of the reservoir, with a great declivity of its margins, a fact that hinders anthropogenic influences. For Epitácio Pessoa, the disturbance metrics confirmed the curve plotted for the higher water volume, where the sites with the higher metrics were associated with the presence of pastures, transmission lines, construction, trade, and trash, reflecting use and occupation around that reservoir.

Our results showed that abundance and biomass curves have the potential to be used as assessment tools for ecological quality in reservoirs in semi-arid regions, showing major relationships with physical and chemical variables, but with information discordant with ecological indicators and disturbance metrics. The ABC method has been applied in temperate and tropical regions (Beukema 1988, Clarke 1990, Reizopoulou et al. 1996, Carvalho et al. 2013); however, as seen in this study, its use has been questioned (Beukema 1988, Reizopoulou et al. 1996). Despite that the curves use abundance and biomass data, and even though they are easy to interpret (Clarke 1990), it is necessary to have knowledge of the ecological aspects of the species that form the community, because when they are not considered, there may be possible errors in the interpretation of curves (Warwick \& Clarke 1990, Reizopoulou et al. 1996). Accordingly, the abundant species in terms of biomass may not always indicate low impact areas, and abundant species based on number of individuals may indicate disturbance sites (Dauer et al. 1993) as occurred in our study. ABC may be used cautiously and combined with other indicators, for a coherent and accurate characterization of the quality of reservoirs.

\section{Acknowledgments}

The authors thank the Universidade Estadual da Paraíba (UEPB/ PROPESQ) for financial support and Laboratório de Ecologia de Bentos and the Laboratório de Ecologia Aquática (UEPB) for their technical support. JM is grateful to project CNPq / MCT/ Universal process n 379 446721/2014 and for research productivity scholarships (process 302393/2017-0). JELB for is grateful to productivity research scholarships (process 302393/2017-0).

\section{Author Contributions:}

Carlinda Raílly Medeiros, Evaldo de Lira Azevêdo, José Etham de Lucena Barbosa and Joseline Molozzi: Substantial contribution in the concept and design of the study.

Carlinda Raílly Medeiros and Evaldo de Lira Azevêdo: Contribution to data collection.

Carlinda Raílly Medeiros and Joseline Molozzi: Contribution to data analysis and interpretation.

Carlinda Raílly Medeiros, Evaldo de Lira Azevêdo and Joseline Molozzi: Contribution to manuscript preparation.

Carlinda Raílly Medeiros, Evaldo de Lira Azevêdo, José Etham de Lucena Barbosa and Joseline Molozzi: Contribution to critical revision, adding intelectual content.

\section{Conflicts of interest}

The authors declare that they have no conflict of interest related to the publication of this manuscript.

\section{References}

ABELLÁN, P., SANCHÉZ-FERNÁNDEZ, D., MILLÁN, A., BOTELLA, B. SÁNCHEZ-ZAPATA, J.A. \& GIMÉNEZ, A. 2006. Irrigation pools as macroinvertebrate habitat in a semi-arid agricultural landscape (SE Spain). Journal of Arid Environments, 67(2): 255-269, https://doi.org/10.1016/j. jaridenv.2006.02.009.

ABÍLIO, F.J.P., RUFFO, T.L.M., SOUZA, A.H.F.F., FLORENTINO, S.H., JUNIOR, E.T.O., MEIRELES, B.N. \& SANTANA, A.C.D. 2007. Macroinvertebrados bentônicos como bioindicadores de qualidade ambiental de corpos aquáticos da Caatinga. Oecologia Brasiliensis, 11(3): 397-409.

AGÊNCIA EXECUTIVA DE GESTÃO DAS ÁGUAS DO ESTADO DA PARAÍBA 2013. Comitê Rio do Paraíba. http://www.aesa.pb.gov.br/comites/paraiba/. Accessed 10 July 2013.

AHRENS, M.A. \& PETER, R.H. 1991. Patterns and limitations in limnoplankton size spectra. Canadian Journal of Fisheries and Aquatic Sciences, 48(10):19671978, https://doi.org/10.1139/f91-234.

ANDERSON, M.J., GORLEY, R.N. \& CLARKE, K.R. 2008. PERMANOVA + for PRIMER: Guide to software and statistical methods, PRIMER-E. Plymouth.

APHA, Awwa. WEF. 2005. Standard methods for the examination of water and wastewater. American Public Health Association, American Water Works Association, and Water Environment Federation.

AZEVÊDO, D.J.S., BARBOSA, J.E.L., GOMES, W.I.A., PORTO, D.E., MARQUES, J.C. \& MOLOZZI, J. 2015. Diversity measures in macroinvertebrate and zooplankton communities related to the trophic status of subtropical reservoirs: Contradictory or complementary responses?. Ecological Indicators, 50:135-149, https://doi.org/10.1016/j.ecolind.2014.10.010.

AZEVÊDO, E.L., BARBOSA, J.E.L., VIANA, L.G., ANACLETO, M.J.P., CALLISTO, M. \& MOLOZZI, J. 2017. Application of a statistical model for the assessment of environmental quality in neotropical semi-arid reservoirs. Environmental Monitoring and Assessment, 189(2): 65, https://link.springer. com/article/10.1007/s10661-016-5723-3.

AZEVÊDO, E.L., BARBOSA, J.E.L., VIDIGAL, T.H.D.A., CALLISTO, M. \& MOLOZZI, J. 2014. First record of Corbicula largillierti (Philippi 1844) in the Paraíba River Basin and potential implications from water diversion of the São Francisco River. Biota Neotropica, 14(4): 1-4, http://dx.doi.org/10.1590/16760603003614

BAPTISTA, D.F. 2008. Uso de macroinvertebrados em procedimentos de biomonitoramento em ecossistemas aquáticos. Oecologia Brasiliensis, 12(3): 425-441.

BARBOSA, J.E.L., MEDEIROS, E.S.F., BRASIL, J., CORDEIRO, R.D.S., CRISPIM, M.C.B. \& SILVA, G.H.G.D. 2012. Aquatic systems in semi-arid Brazil: limnology and management. Acta Limnologica Brasiliensia, 24(1): 103-118, http://dx.doi.org/10.1590/S2179-975X2012005000030.

BEDNAREK, A.T. 2001. Undamming rivers: a review of the ecological impacts of dam removal. Environmental Management, 27(6): 803-814, https://link. springer.com/article/10.1007\%2Fs002670010189? LI=true.

BEUKEMA, J.J. 1998. An evaluation of the ABC-method (abundance/biomass comparison) as applied to macrozoobenthic communities living on tidal flats in the Dutch Wadden Sea. Marine Biology, 99(3): 425-433.

BORJA, A., MILES, A., OCCHIPINTI-AMBROGI, A. \& BERG, T. 2009. Current status of macroinvertebrate methods used for assessing the quality of European marine waters: implementing the Water Framework Directive. Hydrobiologia, 633(1): 181-196, https://link.springer.com/article/10.1007/s10750-009-9881-y.

BUSS, D.F., BAPTISTA, D.F. \& NESSIMIAN, J.L. 2003. Conceptual basis for the application of biomonitoring on stream water quality programs. Cadernos de Saúde Pública, 19(2): 465-473, http://dx.doi.org/10.1590/S0102-311X2003000200013.

CALLISTO, M., GOULART, M., BARBOSA, F.A.R. \& ROCHA, O. 2005, Biodiversity assessment of benthic macroinvertebrates along a reservoir cascade in the lower São Francisco river (northeastern Brazil). Brazilian Journal of Biology, 65(5): 229-240, http://dx.doi.org/10.1590/S1519-69842005000200006.

CAMARGO, J.A., GONZALO, C. \& ALONSA, Á. 2011. Assessing trout farm pollution by biological metrics and indices based on aquatic macrophytes and benthic macroinvertebrates: A case study. Ecological Indicators, 11(3): 911-917, https://doi.org/10.1016/j.ecolind.2010.10.001.

CARVALHO, F.G., JUNIOR, J.M.B.O., FARIAS, A.P.J. \& JUEN, L. 2013. Uso da curva $\mathrm{ABC}$ como método para detectar o efeito de modificação antropogênica sobre assembleia de Odonata (insecta). Interciencia, 38(7): 516-522. 
CLARKE, K.R. Comparisons of dominance curves. 1990. Journal of Experimental Marine Biology and Ecology, 138(1): 143-157.

CLARKE, K.R. \& GORLEY, R.N. 2006. Primer v6: USER manual. PRIMER-E Ltd. Plymouth Marine Laboratory, 192.

CLARKE, K.R. \& WARWICK, R.M. 2001. Change in marine communities: An approach to statistical analysis and interpretation. 2nd Ed. PRIMER-E Ltd, Plymouth Marine Laboratory, 172.

DAUER, D.M., LUCKENBACH, M.W. \& RODI-JR. A.J. 1993. Abundance biomass comparison ( $\mathrm{ABC}$ method): effects of an estuarine gradient, anoxic/hypoxic events and contaminated sediments. Marine Biology, 116(3): 507-518, https:// link.springer.com/article/10.1007\%2FBF00350068?LI=true.

ELKARMI, A.Z. \& ISMAIL, N.S. 2007. Growth models and shell morphometrics of two populations of Melanoides tuberculata (Thiaridae) living in hot springs and freshwater pools. Journal of Limnology, 66(2): 90-96, https://doi.org/10.4081/ jlimnol.2007.90.

GOLTERMAN, H.L., CLYMO, R.S. \& OHNSTAD, M. 1978. Methods for physical and chemical analysis of freshwaters. 2 Ed. Oxford: Blackwell Scientific Publications $\mathrm{Ib}$.

HARKANTRA, S.N. \& RODRIGUES, N.R. 2004. Numerical analyses of soft bottom macroinvertebrates to diagnose the pollution in tropical coastal waters. Environmental Monitoring and Assessment, 93(1-3): 251-275, https://link. springer.com/article/10.1023/B:EMAS.0000016800.86679.62.

JøRGENSEN, P.E., ERIKSEN, T. \& JENSEN, B.K. 1992. Estimation of viable biomass in wastewater and activated sludge by determination of ATP, oxygen utilization rate and FDA hydrolysis. Water Research, 26(11): 1495-1501, https:// doi.org/10.1016/0043-1354(92)90069-G.

KAUFMANN, P.R., PECK, D.V., PAULSEN, S.G., SEELIGER, C.W., HUGHES, R.M., WHITTIER, T.R. \& KAMMAN, N.C. 2014. Lakeshore and littoral physical habitat structure in a national lakes assessment. Lake and Reservoir Management, 2014, 30(2): 192-215.

KÖPPEN, W. \& GEIGER, R. 1936. Handbuch der Klimatologie. Berlin: Gebrüder Bornträger.

LORENZEN, C.J. 1967. Determination of chlorophyll and pheo $\square$ pigments: spectrophotometric equations. Limnology and oceanography, 12(2): 343-346, http://onlinelibrary.wiley.com/doi/10.4319/lo.1967.12.2.0343/full.

MAGURRAN, A.E. 2013. Medindo a diversidade biológica. Curitiba: Editora UFPR.

MARQUES, J., SALAS, F., PATRÍCIO, J., TEIXEIRA, H. \& NETO, J.M. 2009. Ecological indicators for coastal and estuarine environmental assessment. Boston: Wit Press.

MOLOZZI, J., FEIO, M.J., SALAS, F., MARQUES, J.C. \& CALLISTO, M. 2013. Maximum ecological potential of tropical reservoirs and benthic invertebrate communities. Environmental Monitoring and Assessment, 185(8): 6591-6606, https://ink.springer.com/article/10.1007/s10661-012-3049-3.

MUGNAI, R., NESSIMIAN, J.L. \& BAPTISTA, D.F. 2010. Manual de identificação de macroinvertebrados aquáticos do Estado do Rio de Janeiro. Rio de Janeiro: Technical Books Editora.

OTERMIN, A., BASAGUREN, A. \& POZO, J. 2002. Re-colonization by the macroinvertebrate community after a drought period in a first-order stream (Agüera Basin, Northern Spain). Limnetica, 21(2): 117-128.

PESO, J.G., PÉREZ, D.C. \& VOGLER, R.E. 2011. The invasive snail Melanoides tuberculata in Argentina and Paraguay. Limnologica Ecology and Management of Inland Waters, 41(4): 281-284, https://doi.org/10.1016/j.limno.2010.12.001.

POPE, K.L. \& HANNELLY, E.C. 2013. Response of benthic macroinvertebrates to whole-lake, non-native fish treatments in mid-elevation lakes of the Trinity Alps, California. Hydrobiologia, 714(1): 201-215, https://ink.springer.com/ article/10.1007/s10750-013-1537-2.

PUENTE, A. \& DIAZ, R.J. 2008. Is it possible to assess the ecological status of highly stressed natural estuarine environments using macroinvertebrates indices?. Marine Pollution Bulletin, 56(11): 1880-1889, https://doi.org/10.1016/j. marpolbul.2008.07.016

REIZOPOULOU, S., THESSALOU-LEGAKI, M. \& NICOLAIDOU, A. 1996. Assessment of disturbance in Mediterranean lagoons: An evaluation of methods. Marine Biology, 125(1), 189-197.

ROCHA, L.G., MEDEIROS, E.S.F. \& ANDRADE, H.T.A. 2012. Influence of flow variability on macroinvertebrate assemblages in an intermittent stream of semiarid Brazil. Journal of Arid Environments, 85, 33-40, https://doi.org/10.1016/j. jaridenv.2012.04.001.
SANTOS, C.M. \& ESKINAZI-SANT'ANNA, E.M. 2010. The introduced snail Melanoides tuberculatus (Muller, 1774) (Mollusca: Thiaridae) in aquatic ecosystems of the Brazilian Semiarid Northeast (Piranhas-Assu River basin, State of Rio Grande do Norte). Brazilian Journal of Biology, 70(1): 1-7, http:// dx.doi.org/10.1590/S1519-69842010000100003.

SHARMA, R.C. \& RAWAT, J.S. 2009. Monitoring of aquatic macroinvertebrates as bioindicator for assessing the health of wetlands: A case study in the Central Himalayas, India. Ecological Indicators, 9(1): 118-128, https://oi.org/10.1016/j. ecolind.2008.02.004

SHANNON, C.E. \& WEAVER, W. 1963. The mathematical theory of communication. Chicago: University of Illinois Press.

STATZNER, B. \& BÊCHE, L.A. 2010. Can biological invertebrate traits resolve effects of multiple stressors on running water ecosystems? Freshwater Biology, 55(1): 80-119, http://onlinelibrary.wiley.com/doi/10.1111/j.1365-2427.2009.02369.x/full.

TAFANGENYASHA, C. \& DUBE, L.T. 2008. An investigation of the impacts of agricultural runoff on the water quality and aquatic organisms in a Lowveld Sand river system in Southeast Zimbabwe. Water Resources Management, 22(1): 119130, https://link.springer.com/article/10.1007\%2Fs11269-006-9147-7?LI=true.

TAKAHASHI, M.A., HIGUTI, J., BAGATINI, Y.M., ZVIEJKOVSKI, I.P. \& VELHO, L.F.M. Composition and biomass of larval Chironomidae (Insecta, Diptera) as potential indicator of trophic conditions in southern Brazil Reservoirs. Acta Limnologica Brasiliensia, 2008, 20(1): 5-13, http://www.ablimno.org.br/acta/ pdf/acta20_vol1_02.pdf.

THORNE, R. \& WILLIAMS, P. 1997. The response of benthic macroinvertebrates to pollution in developing countries: a multimetric system of bioassessment. Freshwater Biology, 37(3): 671-686, http://onlinelibrary.wiley.com/doi/10.1046/ j.1365-2427.1997.00181.x/full.

THOMPSON, S.A., THOMPSON, G.G. \& WITHERS, P.C. 2008. Rehabilitation index for evaluating restoration of terrestrial ecosystems using the reptile assemblage as the bio-indicator. Ecological Indicators, 8(5): 530-549, https:// doi.org/10.1016/j.ecolind.2007.07.001.

TRIVINHO-STRIXINO, S. \& STRIXINO, G. 1995. Larvas de Chironomidae (Diptera) do Estado de São Paulo: Guia de Identificação e Diagnose dos Gêneros. São Carlos-SP: PPG-ERN/UFSCAR.

TRIVINHO-STRIXINO, S. 2011. Larvas de Chironomidae, Guia de Identificação. Departamento Hidrologia Entomologia Aquática/UFSCAR, São Carlos.

TUNDISI, J.G., MATSUMURA-TUNDISI, T. \& TUNDISI, J.E.M. 2008. Reservoirs and human well being: new challenges for evaluating impacts and benefits in the neotropics. Brazilian Journal of Biology, 68(4), 1133-1135, http://dx.doi. org/10.1590/S1519-69842008000500020.

UNITED STATES ENVIRONMENTAL PROTECTION AGENCY. 2012. National lakes assessment field operations manual EPA 841-B-11-003. Washington. DC: U.S. Environmental Protection Agency.

VARNOSFADERANY, M.N., EBRAHIMI, E., MIRGHAFFARY, N. \& SAFYANIAN, A. 2010. Biological assessment of the Zayandeh Rud River, Iran, using benthic macroinvertebrates. Limnologica-Ecology and Management of Inland Waters, 40(3): 226-232, https://doi.org/10.1016/j.limno.2009.10.002.

VELHO, L.F.M., PEREIRA, D.G., PAGIORO, T.A., SANTOS, V.D., PERENHA, M.C.Z. \& LANSAC-TÔHA, F.A. 2005. Abundance, biomass and size structure of planktonic ciliates in reservoirs with distinct trophic states. Acta Limnologica Brasiliensia, 17(4): 361-371, http://ablimno.org.br/acta/pdf/acta_limnologica_ contents1704E_files/17_2(4).pdf.

WARWICK, R.M. \& CLARKE, K.R. 1994. Relearning the ABC: taxonomic changes and abundance/biomass relationships in disturbed benthic communities. Marine Biology, 118: 739-744, https://link.springer.com/article/10.1007\%2FBF0034 7523 ? LI=true.

WARWICK, R. 1986. A new method for detecting pollution effects on marine macrobenthic communities. Marine Biology, 92(4): 557-562, https://link. springer.com/article/10.1007/BF00392515.

YEMANE, D., FIELD, J.G. \& LESLIE, R.W. 2005. Exploring the effects of fishing on fish assemblages using Abundance Biomass Comparison (ABC) curves. ICES Journal of Marine Science: Journal du Conseil, 62(3): 374-379, https:// doi.org/10.1016/j.icesjms.2005.01.009. 